\title{
Queen adoption in colonies of the leaf-cutting ant Acromyrmex subterraneus molestans (Hymenoptera: Formicidae)
}

\author{
Danival J. Souza ${ }^{a, b}$, Terezinha M.C. Della Lucia ${ }^{a}$,*, Eraldo R. Lima ${ }^{\text {a }}$ \\ a Departamento de Biologia Animal, Universidade Federal de Viçosa, Viçosa MG 36570-000, Brasil \\ ${ }^{\mathrm{b}}$ Institut de Recherche sur la Biologie de l'Insecte, Faculté des Sciences et Techniques, Tours 37200, France
}

Received 5 May 2004; received in revised form 22 April 2005; accepted 25 April 2005

\begin{abstract}
Bioassays were conducted in both laboratory and the field to determine if monogynous colonies of Acromyrmex subterraneus molestans (Myrmicinae, Attini) adopt queens from other colonies of the same subspecies. The results suggest that the adoption of fertilized queens is a possible mechanism to explain the occurrence of colonies with multiple queens in this subspecies. Only minor workers were able to discriminate queens from other colonies and were aggressive toward them. Therefore, queen recognition differs among subcastes.
\end{abstract}

(C) 2005 Elsevier B.V. All rights reserved.

Keywords: Polygyny; Attini; Queen adoption; Social behavior

\section{Introduction}

Variation in the number of queens in colonies of social insects has been a subject of increased interest among sociobiologists. This is emphasized by the increased evidence that polygyny, i.e. mature colonies with more than one queen, is more common than it was previously thought (Keller and Vargo, 1993). In ants it may be the predominant social structure (Rissing and Pollock, 1988; Frumhoff and Ward, 1992). Therefore, polygyny represents a challenge to the theory of kin-selection since the reproductive task is shared and

\footnotetext{
* Corresponding author.

E-mail address: tdlucia@ufv.br (T.M.C. Della Lucia).
}

the genetic relatedness among colony members can become very low (Nash and Bernasconi, 1996).

Two types of polygyny have been recognized in ants: primary and secondary. When more than one fertilized female get together to found one colony (pleometrosis), this may give rise to primary polygyny. Pleometrosis has been well documented in ants (Bartz and Hölldobler, 1982; Tschinkel and Howard, 1983; Pollock and Rissing, 1985). In the genus Acromyrmex Mayr 1865 pleometrosis was observed in the field in Ac. versicolor (Rissing et al., 1986) and has been demonstrated under laboratory conditions in Ac. striatus (Diehl-Fleig and Araújo, 1996). Rissing et al. (1986) reported up to 16 queens occupying the same nest immediately after nest foundation. Secondary polyg- 
yny arises when colonies that were established by single queens (haplometrosis) become polygynous by gyne acceptance, i.e. workers allow other queens to enter and become established in their nest (Herbers, 1993). These arrivals are usually new fertilized queens adopted by the established nest. Moreover, two monogynous colonies may join into one. The adoption of new queens by an established colony of Acromyrmex has not yet been observed in nature but we have observed several young colonies of Ac. subterraneus molestans separated by small distances $(\sim 10-15 \mathrm{~cm})$. It is possible that through colony growth they can be joined.

Polygyny has evolved several times in ants; usually it is of the secondary type and has arisen due to the adoption of new queens (Hölldobler and Wilson, 1977, 1990). This would be advantageous since the rate of success of an independent colony foundation is very low (Nonacs, 1988; Pamilo, 1991). Also, high number of breeders is an efficient strategy to face perturbations and catastrophic events, as well as to monopolize patches of habitats (Chapuisat and Crozier, 2001). Studies on the dynamics of queen acceptance are the central point for the understanding of: (1) the proximate mechanisms involved in the regulation of queen number-to understand how polygyny arises and how it is maintained and (2) the ultimate causes, e.g. the evolution of polygyny (Sundström, 1997). A number of studies have emphasized recognition among nestmate and nonnestmate workers. However, little attention has been given to the discriminatory behavior of workers toward reproductive females, in spite of the relevance of this behavior to the regulation of queen number in the colony. Workers should be able to discriminate among nestmate and non-nestmate foundress as well as among mated and unmated females (Sundström, 1997).

This work tries to answer the following questions:

(1) Do monogynous colonies of the subspecies Ac. subterraneus molestans maintained in laboratory adopt new queens from the same subspecies?

(2) Do workers of a mature field colony accept fertile queens originated from another colony of the same subspecies?

(3) In the field, colonies may be initiated via pleometrotic associations?

\section{Materials and methods}

\subsection{Colony maintenance}

Five one-year-old colonies of Ac. subterraneus molestans $\left(\mathrm{C}_{1}, \mathrm{C}_{2}, \mathrm{C}_{3}, \mathrm{C}_{4}, \mathrm{C}_{5}\right)$, with an average fungus volume of $600 \mathrm{~mL}$, were maintained at the Insectary of the Federal University of Viçosa as described by Della Lucia et al. (1993). They were daily fed the same kind of leaves (Acalypha sp. and Ligustrum sp.) and were supplied with water. Room temperature was $25 \pm 2.5^{\circ} \mathrm{C}$; relative humidity 70 to $80 \%$ and 10:14 L:D.

\subsection{Offering of reproductive queens from other colonies}

All five colonies had their leaf-supply interrupted $6 \mathrm{~h}$ before the bioassays began so that there was no leafcutting and carrying in at the moment of the test in all treatments. This procedure also favored visualization because the arena was free from leaves and petals.

\subsubsection{Treatment 1: queen from same colony (QSC)}

The queen was removed from the colony, marked with a color dot on the gaster and placed on a plastic recipient covered by a moistened cotton swab $15 \mathrm{~min}$ before the beginning of the experiments. She was then transferred to an open glass tube $(6 \mathrm{~cm} \times 2.2 \mathrm{~cm}$; height $\times$ diameter) and was offered to the colony in the foraging arena. The glass tube was laid horizontally on the arena so that the workers had easy access to its interior; the queen could also leave the tube. Queen and workers behavior were observed and the time of queen acceptance or rejection was recorded. Queen from its own colony was offered once to each one of the five colonies. Acceptance was considered as the entrance of the queen into the nest at a 30-min interval.

\subsubsection{Treatment 2: queen from other colony (QOC)}

The procedure followed during this bioassay was identical to that of treatment 1 , but the queen used in this treatment belonged to a monogynous colony recently collected in the field. These field colonies were very small (average fungus volume of $150 \mathrm{~mL}$ ) and probably newly founded. Three field queens were offered to each one of the five laboratory colonies, at 5-day intervals between each replication. Three months after offering 
of the last queen they were still together and oviposited. Egg-laying was evaluated according to Marinho and Della Lucia (1998). QSC and QOC were weighted and transferred individually to a plastic recipient provided with a honey-water solution in a cotton piece. The lids of the recipients were perforated and covered with a moistened cotton swab in these recipients during $72 \mathrm{~h}$ for egg-laying evaluation.

\subsection{Offering of queens from other colonies to a field colony of the same subspecies}

Four previously marked queens from different small colonies ( $150 \mathrm{~mL}$ fungus garden volume) were offered to a field colony. It was located at the campus of the Federal University of Viçosa. It had two nest entrance holes and the foraging activity of workers could be followed. Each queen was marked with a color dot on the gaster and was offered to the field colony $24 \mathrm{~h}$ after marking at 2-day intervals at a nest entrance. Behavior of both queen and workers was recorded.

The head capsule widths of the workers that contacted the queen at the foraging arena were measured (Wilson, 1980). These workers were collected in several occasions during the bioassays.

\subsection{Observation of foundress behavior}

We monitored nest foundation during the first 10 days of November 2002 and 2003 to identify colony foundress strategy in Ac. subterraneus molestans. Starting nests were recognized by a characteristic semicircular mound of soil around the nest entrance. Sixty nests were excavated and all foundresses inside the nest collected.

\section{Results and discussion}

\subsection{Acceptance of queens from same colonies (QSC)}

The average time taken by the queens to leave or to be removed from the glass vials was $5.43 \pm 4.76 \mathrm{~min}$ $(n=5)$. Workers response to the queen was similar in all of the colonies. Several workers aggregated around the glass vial where the queen had been placed. Others got inside the glass and started antennating the queen without any kind of aggressive behavior. The average time for accepting the queen was $11.59 \pm 6.77 \mathrm{~min}$. Acceptance was considered as the entrance of the queen into the nest. As expected, none of the queens from their own colonies was rejected. Of five QSC that were offered, three went inside the nests by themselves and two were carried by the workers. They were carried always in the same position, e.g. they curled their legs and antennae and became immobile. According to Wilson (1971), the behavior of a transporting nestmate worker and of the individual being transported is characteristic of the members of each subfamily.

\subsection{Acceptance of queens from other colonies (QOC)}

When the offered queen belonged to other colony (QOC), the average time she took to leave the glass vial was $2.77 \pm 2.0 \mathrm{~min}(n=15)$. Of $13 \mathrm{QOC}$ that were accepted, 7 went inside the nests by themselves and 6 were carried by the workers. Transporting position was identical to that of the QSC and it was always performed by a media worker (1.4 $\mathrm{mm}$ head capsule width, on average). Two queens (QOC) were rejected and severely attacked by several workers when leaving the glass vials. The mean time spent by QOC to enter the nest was $7.52 \pm 2.62$ (the first queen), $8.63 \pm 7.36$ (the second queen) and $10.23 \pm 7.71 \mathrm{~min}$ (the third queen). The time of acceptance of queens from other colonies did not differ in the three occasions, neither did the time of acceptance of QOC (ANOVA; $F_{3,14}=0.39 ; p=0.76$ ) (Fig. 1). Table 1 summarizes the data on the offering of queens from other colonies (QOC). In four situations, rejections occurred after initial acceptance. The rejection times were: $5 \mathrm{~min}, 14,16$ and $96 \mathrm{~h}$, after initial queen acceptance. Rejection may occur with the first, second, or third queen consecutively offered.

The $\mathrm{C}_{1}$ colony rejected or expelled all queens from other colonies that were tested. Therefore, it remained monogynous, having its own foundress queen. Genetic variations could be associated with this behavior. Krieger and Ross (2002) have demonstrated that a single allelic difference in the locus Gp-9 determines queen number in Solenopsis invicta colonies. Gp-9 is involved in the production of a protein associated to pheromone of individual recognition among colony members. However, Chapuisat et al. (2004) failed in finding genetic differentiation between single- 


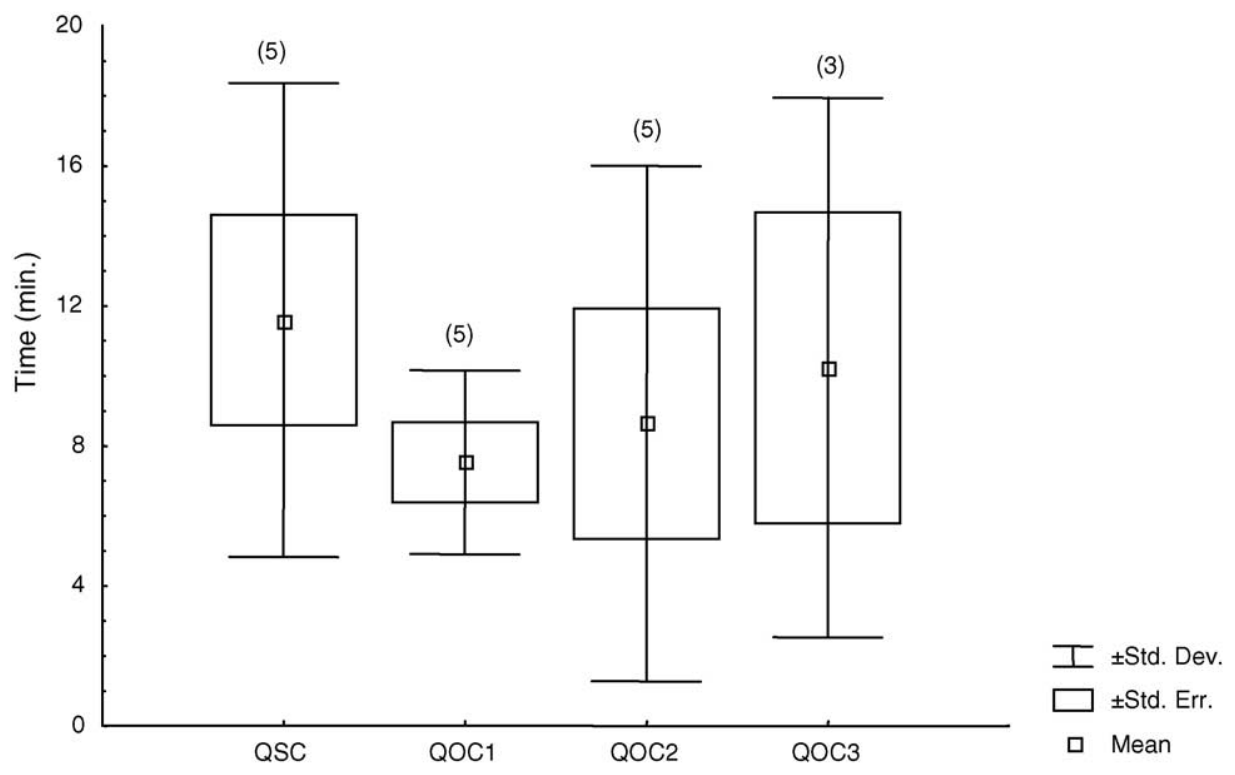

Fig. 1. Average time ( $\mathrm{min}$ ) for acceptance of queens from same colonies (QSC) and queens from other colonies (QOC). Means do not differ significantly (ANOVA, $F_{3,14}=0.39, p=0.76$ ).

and multiple-queen colonies of Formica selysi, which suggests ongoing gene flow between both types of colonies. In addition, we must consider that in many species queen number is a trait strongly influenced by ecological factors (Bourke and Heinze, 1994; Pedersen and Boomsma, 1999; Ingram, 2002). When either initial queen rejection or latter queen expelling occurred, it was verified that only the smallest of all workers (minors) performed these tasks. The average head capsule width of these workers was $0.98 \mathrm{~mm}$, significantly smaller (Mann-Whitney $U$-test at $5 \%$ probability) than the average sized workers that were in the foraging

Table 1

Behavior of Ac. subterraneus molestans colonies when offered queens from other colony (QOC)

\begin{tabular}{|c|c|c|c|}
\hline Colony & $\begin{array}{l}\text { First QOC } \\
\text { offered }\end{array}$ & $\begin{array}{l}\text { Second QOC } \\
\text { offered }\end{array}$ & $\begin{array}{l}\text { Third QOC } \\
\text { offered }\end{array}$ \\
\hline $\mathrm{C}_{1}$ & Accepted $^{\mathrm{a}}$ & Accepted $^{\mathrm{b}}$ & Non-accepted \\
\hline $\mathrm{C}_{2}$ & Accepted & Accepted $^{c}$ & Accepted \\
\hline $\mathrm{C}_{3}$ & Accepted & Accepted & Accepted $^{\mathrm{d}}$ \\
\hline $\mathrm{C}_{4}$ & Accepted & Accepted & Non-accepted \\
\hline $\mathrm{C}_{5}$ & Accepted & Accepted & Accepted \\
\hline
\end{tabular}

${ }^{a}$ Queen expelled $16 \mathrm{~h}$ after initial acceptance.

${ }^{\mathrm{b}}$ Queen expelled $5 \mathrm{~min}$ after initial acceptance.

${ }^{c}$ Queen expelled and mutilated $96 \mathrm{~h}$ after initial acceptance.

d Queen expelled $14 \mathrm{~h}$ after. arena (Table 2). These minima aggregated around the queen and several of them bit the queen's antennae and legs.

Maintenance of artificial polygyny in these colonies evaluated three months after queen acceptance indicated that all of the queens were present and oviposited, thus surpassing the egg-laying rate of the original queen. This demonstrates that artificial polygyny was not a temporary condition and that the adopted queens can contribute to worker production in the colony (Table 3). It may be possible that the entrance of these mature queens or fusion of two nests is rather pacific due to similarities in chemical profiles of different colonies. According to Souza et al. (in press), chemi-

Table 2

Average head capsule width (mm) of workers of Ac. subterraneus molestans which exhibited aggressive behavior toward introduced queens as compared to the other workers at the foraging arena

\begin{tabular}{llll}
\hline Colony & Hostile workers $(\mathrm{mm})$ & Workers at arena & $p$-value \\
\hline $\mathrm{C}_{1}$ & $0.94 \pm 0.182(30)$ & $1.50 \pm 0.241(16)$ & $0.0001^{*}$ \\
$\mathrm{C}_{3}$ & $0.99 \pm 0.354(64)$ & $1.88 \pm 0.366(17)$ & $<0.0001^{*}$ \\
$\mathrm{C}_{4}$ & $1.03 \pm 0.038(31)$ & $1.32 \pm 0.22(28)$ & $<0.001^{*}$ \\
\hline
\end{tabular}

The number of observed workers is in parenthesis.

* Means are significantly different (Mann-Whitney $U$-test, $5 \%$ of probability). 
Table 3

Number of eggs laid by queens from same colonies (QSC) and by queens from other colonies (QOC) of Ac. subterraneus molestans during an interval of $72 \mathrm{~h}$

\begin{tabular}{lcl}
\hline Colonies & $\begin{array}{l}\text { Number of } \\
\text { eggs }(\mathrm{QSC})\end{array}$ & $\begin{array}{l}\text { Number of } \\
\text { eggs }(\mathrm{QOC})^{\mathrm{a}}\end{array}$ \\
\hline $\mathrm{C}_{2}$ & 131 & $144 / 94(238)$ \\
$\mathrm{C}_{3}$ & 0 & $31 / 8(39)$ \\
$\mathrm{C}_{4}$ & 18 & $351 / 65(416)$ \\
$\mathrm{C}_{5}$ & 22 & $91 / 44 / 10(145)$ \\
\hline
\end{tabular}

The sum of the number of eggs of QOC in each colony is in parenthesis.

a Slashes are separating the number of eggs laid by each queen in the association. The total number of eggs is in parenthesis.

cal profiles of different colonies are very similar in this subspecies.

Several researchers have demonstrated that mating status of the introduced females elicit substantial variation in worker response (Fortelius et al., 1993; Evans, 1996; Ross and Keller, 1998). Here, we introduced queens from small field colonies. Although certainly not mature ones, these experimental queens may have been very different physiologically from newly mated queens because they had initiated oogenesis. In further studies, we should investigate the ac- ceptability of the newly mated queens by mature colonies.

There was a positive correlation between body mass of the queen and the number of eggs laid by them in the artificially polygynous colonies (Fig. 2). Dominance and fertility are usually correlated (Heinze, 1993). Therefore, greater egg-laying and consequently the most fertile queen guarantee a higher number of descendants. On the other hand, this advantage may be apparent. Herbers (1993) reported that in situations of acceptance of new queens by already established nests, it is possible that the task of producing sexuals becomes restricted to the resident queen (QSC) and the adopted queens produce only workers.

In this experiment, we found that a group of the smallest workers was able to discriminate efficiently the queen offered from another colony. These minors aggregated themselves in sufficiently large numbers to disturb and promote the exit of the queen from the nest. However, these workers were not able to easily mutilate the queen. Besides caring for the fungus garden, these minima workers usually care for the queen and the eggs. This could give a greater discriminatory ability to this group of workers in contrast to the foragers, for example, that do not get in close contact with the

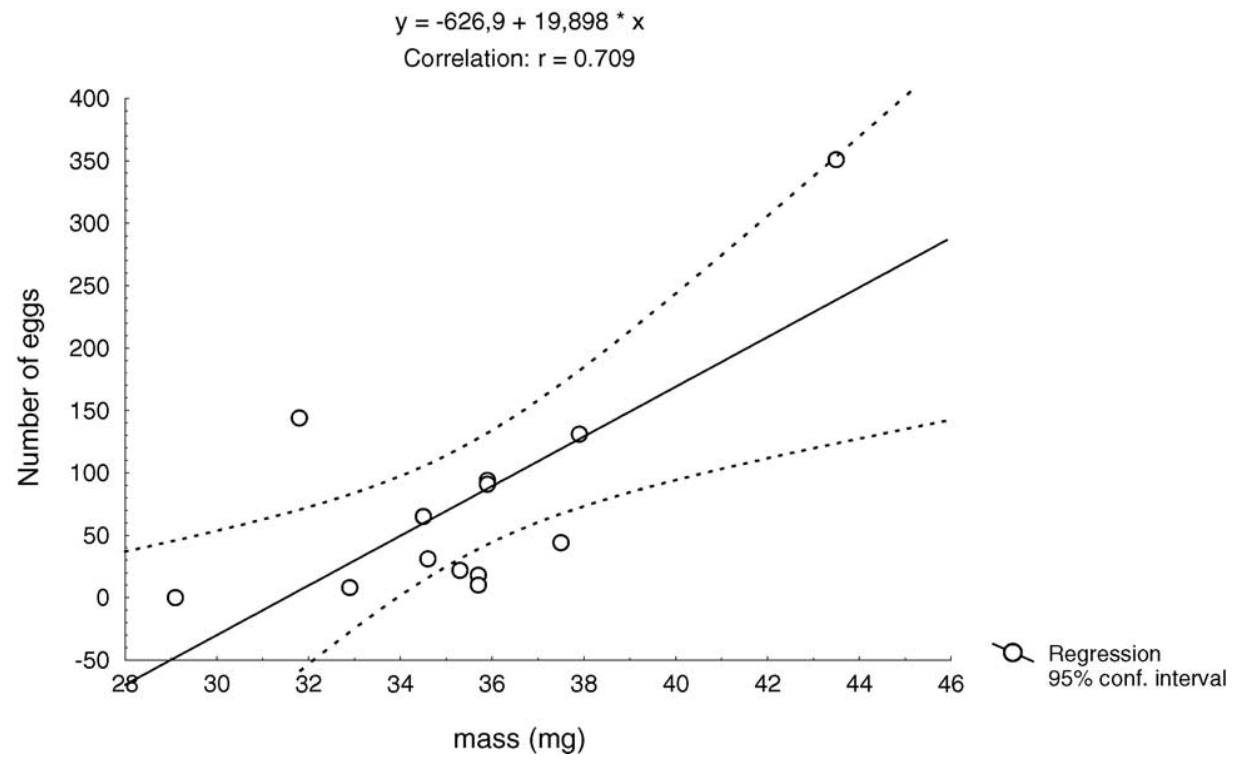

Fig. 2. Relationship between egg-laying $(y)$ in an interval of $72 \mathrm{~h}$ and the body mass of queens $(x)$ which remained in association three months after adoption ( $n=13$ queens). 
queen. Viana (1996) also reported that the minor workers (gardeners and nurses) of Ac. subterraneus subterraneus are more efficient to discriminate alien brood than the foragers.

\subsection{Acceptance of queens from other colonies by a field colony}

The four queens offered to the field colony entered the nest in less than one minute. Upon nest excavation 10 days after offering the fourth queen, two marked and introduced queens were found together with two original ones. Maybe the two missing queens were not accepted or were not found due to the difficulties in nest excavation, since the nest chamber was located among soil cracking. The two adopted queens were found in the middle of the fungus garden and were cared for by the workers. This emphasizes the idea that adoption of fertilized queens might occur in the field. During the first 10 days of November, 2002 and 2003 it was possible to observe queens of Ac. subterraneus molestans searching for nesting sites. Sixty of these newly founded nests were excavated in a place where mature polygynous colonies have been frequently collected. However, we could not find any gathering of queens at that time. Rissing et al. (1986) found 56\% frequency of pleometrosis in 64 nests of Ac. versicolor. It is known that distinct ecological pressures could be determining the main kind of nest foundation: haplometrosis or pleometrosis (revised by Herbers, 1993; Bourke and Heinze, 1994). Acromyrmex versicolor occurs in certain regions of the Arizona desert (USA) where the shades given by a few existing shrubs constitute a very scarce resource: nesting site. In that situation, gathering of foundress queens would be advantageous. The proportion of polygynous colonies of $A c$. subterraneus molestans in the urban areas of Viçosa has been estimated to be 15-20\% (unpublished data). The nests of this subspecies are very superficial when compared to other Acromyrmex species. We have observed their colonies migrating due to any small disturbance. According to Hölldobler and Wilson (1977), for species inhabiting fragile nest sites, colony breakup after physical disturbance would leave orphaned fragments. Therefore, the presence of multiple queens in the nest would be a strategic behavior, such that each fragment would more likely possess a mated egglayer.
It is not unlikely that egg-laying queens of $A c . s u b$ terraneus molestans are adopted by another nest. Brood raiding among incipient colonies of Ac. versicolor has been verified by Rissing et al. (1989) under laboratory conditions. In a similar bioassay, we investigate the behaviour of incipient colonies of Ac. subterraneus molestans. It was possible to observe intense intercolony brood raiding and queens were transported by workers of rival nests (unpublished data).

\subsection{Observation of foundress behavior}

The fact that no pleometrotic nest foundation in $A c$. subterraneus molestans was observed does not mean pleometrosis does not occur in this subspecies. Although sampling of excavated nests was low $(n=60)$, it may indicate that pleometrosis is rather an uncommon phenomenon in the studied area. Based on the laboratory experiments and field observations conducted, queen adoption by established colonies of Ac. subterraneus molestans becomes a possible mechanism to explain the existence of colonies with multiple queens in this subspecies. The utilization of techniques which allow estimating queen age in polygynous colonies would confirm the hypothesis that queen adoption in Ac. subterraneus molestans is a phenomenon that occurs in nature.

This work showed that colonies of Ac. subterraneus molestans adopt queens from other colonies of the same subspecies and that adopted queens lay eggs and may contribute to greater colony development.

\section{Acknowledgements}

We wish to express our sincere thanks to Dr. Lucio Campos, Dr. Luiz Cláudio Barbosa and Dr. Mara Garcia Tavares at Federal University of Viçosa and two anonymous reviewers for their comments on the preparation of the manuscript. The authors were supported by a grant from CNPq.

\section{References}

Bartz, S.H., Hölldobler, B., 1982. Colony founding in Myrmecocystus mimicus wheeler and the evolution of foundress associations. Behav. Ecol. Sociobiol. 10, 137-147. 
Bourke, A.F.G., Heinze, J., 1994. The ecology of communal breeding: the case of multiple-queen leptothoracine ants. Philos. Trans. R. Soc. London B 345, 359-372.

Chapuisat, M., Crozier, R., 2001. Low relatedness among cooperatively breeding workers of the greenhead ant Rhytidoponera metalica. J. Evol. Biol. 14, 564-573.

Chapuisat, M., Bocherens, S., Rosset, H., 2004. Variable queen number in ant colonies: no impact on queen turnover, inbreeding, and population genetic differentiation in the ant Formica selysi. Evolution 58, 1064-1072.

Della Lucia, T.M.C., Vilela, E. F., Anjos, N., 1993. Criação de formigas cortadeiras em laboratório. In: Della Lucia, T.M.C. (Ed.), As formigas cortadeiras. Folha de Viçosa, Viçosa.

Diehl-Fleig, E., Araújo, A.M., 1996. Haplometrosis and pleometrosis in the ant Acromyrmex striatus (Hymenoptera: Formicidae). Insect Soc. 43, 47-51.

Evans, J.D., 1996. Queen longevity, queen adoption, and posthumous indirect fitness in the facultatively polygynous ant Myrmica tahoensis. Behav. Ecol. Sociobiol. 39, 275-284.

Fortelius, W., Rosengren, R., Cherix, D., Chautems, D., 1993. Queen recruitment in a highly polygynous supercolony of Formica lugubris (Hymenoptera: Formicidae). Oikos 67, 193200.

Frumhoff, P.C., Ward, P.S., 1992. Individual-level selection, colonylevel selection, and the association between polygyny and worker monomorphism in ants. Am. Nat. 139, 559-590.

Heinze, J., 1993. Habitat structure, dispersal strategies and queen number in two boreal Leptothorax ants. Oecologia 96, 3239.

Herbers, J.M., 1993. Ecological determinants of queen number in ants. In: Keller, L., (Ed.), Queen Number and Sociality in Insects. Oxford University Press, Oxford.

Hölldobler, B., Wilson, E.O., 1977. The number of queens: an important trait in ant evolution. Naturwissenschaften 64, 815.

Hölldobler, B., Wilson, E.O., 1990. The Ants. Belknap, Cambridge.

Ingram, K.K., 2002. Plasticity in queen number and social structure in the invasive Argentine ant (Linepithema humile). Evolution 56, 2008-2016.

Keller, L., Vargo, E. L., 1993. Reproductive structure and reproductive roles in colonies of eusocial insects. In: Keller, L. (Ed.), Queen Number and Sociality in Insects. Oxford University Press, Oxford.

Krieger, M.J.B., Ross, K.G., 2002. Identification of a major gene regulating complex social behavior. Science 295 , 328-332.
Marinho, C.G.S., Della Lucia, T.M.C., 1998. Egg-laying in Acromyrmex spp. (Hymenoptera, Formicidae) under laboratory conditions. Biociências 6, 71-79.

Nash, D., Bernasconi, G., 1996. Ant colonies as an evolutionary paradigm. Q. Rev. Biol. 71, 387-390.

Nonacs, P., 1988. Queen number in colonies of social Hymenoptera as a kin-selected adaptation. Evolution 42, 566-580.

Pamilo, P., 1991. Evolution of colony characteristics in social insects: II. Number of reproductive individuals. Am. Nat. 138, 412-433.

Pedersen, J.S., Boomsma, J.J., 1999. Effect of habitat saturation on the number and turnover of queens in the polygynous ant myrmica sulcinodis. J. Evol. Biol. 12, 903-917.

Pollock, G.B., Rissing, S.W., 1985. Mating season and colony foundation of the seed-harvester ant. Veromessor pergandei. Psyche 92, 125-134.

Rissing, S.W., Johnson, R.A., Pollock, G.B., 1986. Natal nest distribution and pleometrosis in the desert leaf-cutter ant Acromyrmex versicolor (Pergande) (Hymenoptera: Formicidae). Psyche 93, 177-186.

Rissing, S.W., Pollock, G.B., 1988. Pleometrosis and polygyny in ants. In: Jeanne, R.L. (Ed.), Interindividual behavioural variability in social insects. Boulder, Westview.

Rissing, S.W., Pollock, G.B., Higgens, M.R., Hagen, R.H., Smith, D.R., 1989. Foraging specialization without relatedness or dominance among co-founding ant queens. Nature 338, 420-422.

Ross, K.G., Keller, L., 1998. Genetic control of social organization in an ant. Proc. Natl. Acad. Sci. U.S.A. 95, 14232-14237.

Souza, D. J., Della Lucia, T M. C., Barbosa, L. C. A., in press. Discrimination between workers from monogynic and polygynic colonies of Acromyrmex subterraneus molestans (Santschi, 1925).

Sundström, L., 1997. Queen acceptance and nestmate recognition in monogyne and polygyne colonies of the ant Formica truncorum. Anim. Behav. 53, 499-510.

Tschinkel, W.R., Howard, D.F., 1983. Colony founding by pleometrosis in the fire ant Solenopsis invicta. Behav. Ecol. Sociobiol. 12, 103-113.

Viana, A. M. M., 1996. La reconnaissance coloniale du couvain et du champignon chez la fourmi champignonniste Acromyrmex subterraneus subterraneus. Ph.D. thesis, Tours, Université Paris XIII, $136 \mathrm{p}$.

Wilson, E.O., 1971. Insect Societies. Harvard University, Cambridge. Wilson, E.O., 1980. Caste and division of labor in leaf-cutter ants (Hymenoptera, Formicidae Atta). 1. The overall pattern in Atta sexdens. Behav. Ecol. Sociobiol. 7, 157-165. 